\title{
Linguistic Aspects of Intercultural Communication
}

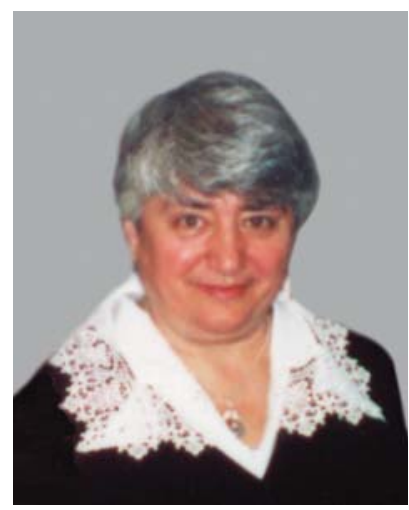

Svetlana Ter-Minasova

7 he problems of communication in general and intercultural communion in particular have become especially urgent nowadays for very obvious social, political, economic and other reasons.

It has become crystal-clear that the future of mankind depends on the so-called "human factor", i.e. on whether people of different nations, ethnic groups representing different cultures will manage to find a common language.

That is why, the linguistic aspects of intercultural communication, no matter how obvious and widelyknown they might seem to be, have acquired paramount importance in modern linguistics.

It should be noted that the term "intercultural communication”, which was practically unknown in Russia some fifteen years ago, has become extremely popular nowadays.

The thing is that "the human factor" I have just mentioned implies two barriers on the way of human communication: language and culture.

The language barrier is known from the time of the Tower of Babel. The cultural barrier is unseen until a clash between your own indigenous culture and an alien one takes place. At best these clashes are surprising, but usually they are simply off-putting or shocking (hence the term culture shock).

Thus, the cultural barrier is far more dangerous than the language barrier. It is made, as it were, of absolutely transparent glass and is imperceptible until one ends up with a black eye, having bumped into it. It is dangerous too in that cultural mistakes are usually taken much more to heart than are language mistakes, and this occurs despite the fact that the former are far more excusable: there are no general rules - no grammars of culture, nor dictionaries of culture - to help one avoid cultural mistakes as there are in the case of languages. We all know from our own experience that native speakers are usually very good-natured about the mistakes we make when speaking their language. But cultural mistakes, as a rule, are not forgiven so easily and leave a very negative impression.

This leads to a conclusion: all the intricacies and depth of the problems inherent in inter-linguistic and cross-cultural communication are shown up particularly clearly, and sometimes even acknowledged, in comparison of foreign languages with one's own mother tongue, of foreign cultures with one's own culture. 
Indeed, only knowledge of at least two languages and two cultures reveals - as distant horizons are revealed from mountain tops - certain concealed characteristics and, accordingly, concealed difficulties not visible from the level of one language. From this an important practical conclusion may be drawn: native speakers who teach their mother tongue as a foreign language and who do not know the mother tongue of their students see neither the concealed characteristics, nor the concealed difficulties.

However, as the subject of my talk is "Linguistic aspects of intercultural communication”, it is necessary to state the interrelation between language and culture. They are inseparable. Language is part of culture and culture is part of language. What are the main linguistic difficulties hampering international and intercultural communication?

The interrelation of language and culture is traditionally expressed through widelyused metaphors: language is a mirror of culture, it reflects the world around us and the world inside us. Moreover, it also reflects a people's collective self-consciousness, its mentality, national character, way of life, customs and traditions, moral standards and values, and world outlook.

A language is a treasure-house, repository of culture. Cultural values are stored in all its forms - lexis, grammar, idioms, proverbs, sayings, folklore, fiction and non-fiction, oral and written discourse.

Language is a transmitter, a carrier of culture; it passes on the treasures of national culture that are preserved in it, from generation to generation. In mastering their native language, children also assimilate the generalized cultural experience of preceding generations.

Language is an instrument of culture. It forms the identity of a native speaker by forcing upon him or her the world-view, mentality, attitude to people, etc., inherent in it - in other words, the culture of a people who use this language to commmunicate with one another.

As a mirror, language reflects not culture merely but the whole world surrounding us. It creates, as we all know very well, a language picture of the world. This picture is nation-specific and is imposed on native speakers of the language.

Developing this metaphor with a picture, we assume that language can be presented as a mosaic which is made of small pieces - words and other language units functionally equivalent to words.

Thus, learning a language in general and a foreign language in particular, begins with learning a word - first the sound (oral form) or the look of it (written form) - and then the meaning. The forms of words of different languages are obviously different but their meanings must be same.

You are learning a foreign language in order to be able to communicate, but communication is possible only on the basis of a shared code. To share a code you must know the meanings of foreign words and the meanings must be the same in both languages, for if they are different, the code is not shared.

However, words of different languages denoting the same things may be different in many ways. 
1. The volume of semantics (the sizes of corresponding pieces of the two mosaics). The Russian dom has a broader meaning than the English house: it includes home, building, block of flats, condominium, mansion.

2. Occurence in speech (dom - in a Russian address: Downing Street dom 10; in English it is 10 Downing Street).

3. Stylistic connotations: bagrovy and crimson coincide semantically but bagrovy has negative connotations, while crimson has positive connotations. (Pieces of the two mosaics differ in colour (or shades of colour)).

These are obvious difficulties. Anyhow, the collocational, or lexico-phraseological constraints that govern the use of language are more cocealed and obscured. This means that the compatibility of words in different languages is nation-specific. Why does the English verb to pay (give somebody money for goods, services, etc.,) collocate with such incompatible - from the Russian point of view - nouns as attention, visit, compliments? Why are the Russian word combinations высокая трава (lit., high grass), крепкий чай (lit., firm tea), сильный дождь (lit., strong, powerful rain) translated into English as long grass, strong tea and heavy rain?

There is only one answer to this: each word has its own collocation or valency. And collocation or valency is nation-specific (not universal) in the sense that it is characteristic only of a given word in a given language. The specific character of collocation becomes evident only in juxtaposition to other languages much as one becomes aware of one's own culture through coming into contact (clashing) with an alien culture. Thus, native speakers of a particular language do not see the problem, it never occurs to them that in a certain language tea can be strong and compliments paid.

4. Lexical collocation undermines the foundations of translation and interpretation. Bilingual dictionaries are a case in point. The translation of words with the help of a dictionary that gives "equivalents" of their meanings in another language can lead students astray and encourage them to use foreign words in contexts typical of their own language.

Let us take, for example the very simple (in terms of its commonness) word книга and its English equivalent book. English-Russian dictionaries give this word in its most frequently occurring collocations:

\section{A book on/about birds - книга о жмизни птии,}

A reference book - справочник

A cheque book - чековая книжка

A ration book - карточки

To do the books - вести счета

Our order books are full - мы больше не принимаем заказов

To be in smb's good/bad books - быть на хорошем, плохом счету

I can read her like a book - я вижу ее на сквозь

We must stick to/go by the book - надо действовать по правилам

I'll take a leaf out of your book - я последую твоему примеру

He was brought to book for that - за это его привлекли к ответу. 
Only one of these is translated into Russian as книга. These differences are even more striking in word combinations. One can shock an audience by stating that native speakers of English, as is indicated by the language, do not wash their heads. And, indeed, in the direct sense - with soap and water - they do not. They wash their hair, the equivalent to the Russian word combination мыть голову (lit., to wash one's head). Interestingly enough, the bald also have to say to wash one's hair in English although it would come more naturally to them to say, as in Russian, to wash one's head. The English expression, to wash one's head, is used figuratively and here its meaning is close to the Russian - also figurative - expression намылить кому-нибудь голову/шею (lit., to soap smb.’s head, neck, fig. to reproach smb. severely).

Thus, the "equivalence" of words of different languages seems to be more and more unrealistic, or, rather, less and less probable. But even in those rare cases when all these purely linguistic moments actually correspond in different languages of the full equivalency of these words, one should not forget about extra-linguistic differences, i.e. the fact that both the things and the concepts thereof can differ.

5. Sociocultural connotations.

At this point the equivalence of meanings turns into a real problem. The problem is that the so-called "meaning” of the word (i.e. a reference of a certain complex of sounds or letters to a thing or phenomenon in the real world) is actually a thread connecting the world of speech with the world of reality. Or, rather, it is a path leading from the world of speech to the real world. Then every word of every speech community leads to the world where the language users live.

Talking about words and what lies beyond them, we deal with the following three levels:

1. The level of reality where objects and phenomena live and function.

2. The level of thinking where there are concepts and ideas about real objects and phenomena. The concepts and ideas are determined by culture, ideology, mentality, etc.

3. The level of speech where words live, collocate, function.

At the level of thinking the concepts denoted by "the same" words may differ greatly because they are determined by different cultures, histories, geographies of different peoples.

In other words, even more concealed than the mysteries and unpredictability of lexical collocation, is the conflict between the cultural ideas held by different nations about those things and phenomena in the external world which are designated by "equivalent" words in these languages. These cultural ideas are usually responsible for words in different languages developing various stylistic and cultural connotations.

Thus, even the lexical designation of such a universal notion as the color green arouses great doubt at the level of its absolute lexical equivalence and undoubtedly varies from language to language in view of the word's differing metaphoric and stylistic connotations. The combination зеленые глаза (green eyes) has a poetic, romantic overtone in Russian and suggests an image of bewitching, magical or mermaid's eyes. In English, however, the word combination green eyes is a metaphor for envy and 
contains explicit negative connotations. These negative associations were "introduced" by Shakespeare who, in "Othello", referred to jealousy as a green-eyed monster.

And another example: the Russian word combination черная кошка, just like its English equivalent, black cat, denotes a pet, a cat of black colour. But in Russian culture, according to tradition, a black cat brings bad luck and therefore the word combination causes strong negative associations.

The words in the given examples are equivalent in meaning but different in stylistic and cultural connotations.

The socio-cultural factor, i.e. those socio-cultural structures underlying language structures, totally undermine the idea of "equivalency" of words in different languages having the same meaning, i.e. relating to the same things and phenomena in the external world.

All this becomes especially clear in case of people who are bilingual but monocultural. Of exceptional value in this regard is the information contained in Andrei Makine's book, Le Testament francais.

Andrei Makine, a Russian, was born in 1957 in Krasnoyarsk, Siberia, studied at Moscow State University, and emigrated to France in 1987, where he began writing novels. His fourth book, Le Testament francais, published in 1995, was the first novel in the history of French literature to win two prizes simultaneously: the most prestigious French literary award, the Goncourt prize, and the Medici prize. All Makine's novels are written in French. Since childhood he has been bilingual (Russian and French) (He learnt French from his French grandmother).

The conflict between the reality of life in the Russian world and the French language becomes evident from the following excerpts from this outstanding work.

Speaking about her birthplace, Neuilly-sur-Seine, Makine's grandmother, Charlotte, refers to it as a "village".

She had said it in French but we only knew Russian villages. And a village in Russia is inevitably a ring of izbas, indeed the very word in Russian, derevnya, comes from derevo - a tree, wood. The confusion persisted, despite the clarifications which Charlotte's stories would later bring. At the name of "Neuilly" we had immediate visions of the village with its wooden houses, its herd and its cockerel. And when, the following summer, Charlotte spoke to us for the first time about the certain Marcel Proust: "By the way, we used to see him playing tennis at Neuilly, on the Boulevard Bineau", we pictured the dandy with big languorous eyes (she had shown us his photo) - there among the izbas!

Beneath the fragile patina of our French words Russian reality often showed through. The President of the Republic was bound to have something Stalinesque about him in the portrait sketched by our imagination. Neuilly was peopled with kolkhoznics. 
With the passage of time, this double vision of the world, the ensuing personality split and the on-going conflict of two languages within a single culture, causes more and more inconvenience for the main character. Thus, the use of the two words: the Russian word царь and the French loan word tsar results in a clash of two images in the boy's mind. Languagewise, the words are full equivalents, but the Russian word царь stands for the bloodthirsty tyrant Nicholas II of Soviet history book frame, whereas the French word tsar evokes associations of the elegant young tsar Nicholas II and his beautiful wife, who had come to Paris to attend the ceremony for the laying of the foundation stone of the Alexander III Bridge and of the festive atmosphere of balls and banquets given in honour of the royal couple, i.e. it ties in with the image created in the stories told by the boy's French grandmother.

Thus, language is a mirror of both the external and cultural-conceptual world (the world of culturally dependent concepts), it reflects both of them. This mirror may be said to be distorted because, rather than an objective, impartial view of the world, it provides a subjective, nation-specific view filtered through the prism of a nation's spirit and mind. It would be more correct, therefore, to speak of language as a creative, even magic, rather than a distorting, mirror. Thus, the negative connotations of the word "distorting" can be avoided and the creative, formative role of language in reference to man - underscored. After all, language does more than passively reflect everything that man obtains through his sensual, creative and cultural experience. It (the language) simultaneously forms (i.e. in continuous interaction with mind and culture) the native speaker as a member of the given socio-cultural community by instilling and developing in himlher a system of values, morals, attitudes and behavioral patterns.

Using the widely-spread metaphor about language (or culture) as a picture of the world, one can say that each nation has its own cultural vision of the world as do art movements. One and the same hay stack would be seen quite differently by a realist, impressionist, cubist, or abstract artist and, therefore, look quite different in their reproduction of it. Language can be compared to an artist who paints from life and creates a model of it, real-life objects having been transformed by his creative imagination.

The reflection of the world in language is the collective artistic effort of the nation speaking that language. Along with their mother tongue, each new generation is presented with a complete cultural set which is inherently composed of national character traits, world-view, i.e. vision of the world, systems of values and so on.

Thus, linguistic difficulties - both open and hidden - are the problems that we, teachers of modern languages, have to solve.

To avoid the hidden trap of lexical-phraseological collocability, the student of a foreign language should learn not individual words and their meanings but common and more or less fixed collocations in which these words occur in a language.

In order to let students understand socio-cultural connotations, a new subject has been introduced, which we call "the world of a language under study". This subject is delivered as two parallel courses - one by a native speaker and the other by a representative of the student's indigenous culture. 
To sum up, it is difficult to find a common language, but this task can be solved if we are fully aware of pitfalls on the road to peace and cooperation.

Linguists of the world, teachers of languages, unite in order to shatter barriers linguistic and non-linguistic - that separate people.

\section{Ltiqni, úzuluntsp, úpqu्umunıpujha hunnnnulggnıu}

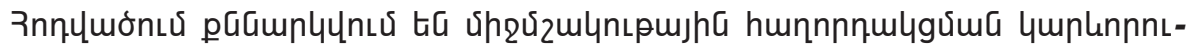

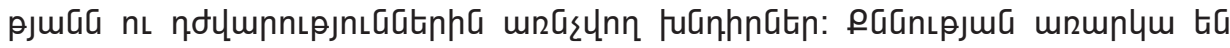

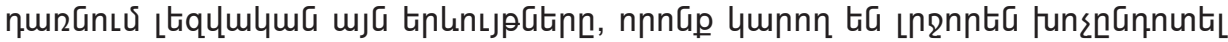

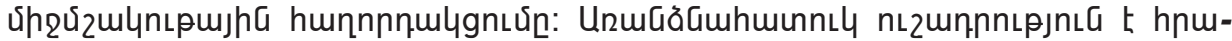

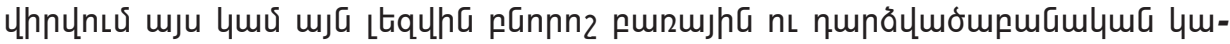

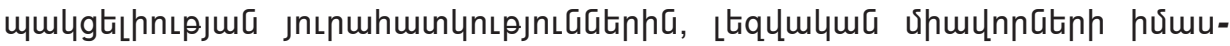

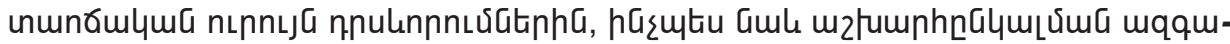

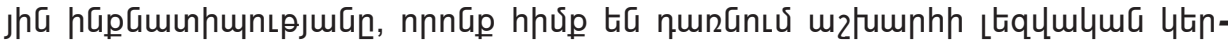

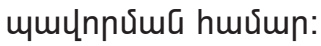

